\title{
From Classroom to Community: An Inquiry of Community-Based Action Research (Through Indigenous Storywork Principles)
}

\author{
Paul Kolenick \\ University of Regina
}

\begin{abstract}
Author Note
I am thankful to the members of the NWRC cohort (2007-2009) who graciously offered their time and insight through interview, as well as their feedback and kind words of encouragement in the writing of this project.
\end{abstract}

\begin{abstract}
Two action research projects of the Community-Based Master of Education program at the University of Regina are featured with particular attention given to a developmental progression that takes place through a series of action research cycles, involving a significant shift from a classroom-based to a community-based teaching practice. In taking an Indigenous perspective on community-based education, this study draws upon Jo-Ann Archibald's (Q'um Q'um Xiiem) (2008) Indigenous Storywork: Educating the Heart, Mind, Body, and Spirit. As an Indigenous approach to life and learning, Archibald's work offers an insightful perspective on communitybased education that is of value to educators with an interest in community development and its potential for schools. In closing, the prospect of educational action research as part of a community-based teaching practice is considered.
\end{abstract}

Keywords: community-based education program; Indigenous storywork; action research 


\section{From Classroom to Community: An Inquiry of Community-Based Action Research (Through Indigenous Storywork Principles)}

Venturing out that summer of 2008 to Northwest Saskatchewan, I had the opportunity to facilitate a course on education for sustainable communities, offered through the CommunityBased Master of Education program at the University of Regina for a cohort of teachers, inschool administrators, consultants, and adult educators. One could not help but notice the care and devotion of this group of educators to the learning of those in their classrooms and schools, in ways, a microcosm of the communities in which they live, work, and belong. This cohort of educators, and their work conducted though the Community-Based program, may be said to exemplify a perspective on community described by Michael and Judie Bopp (2006) as a place of sustained relationships upon which educators (and schools) rely upon for support, encouragement, and inspiration. As teachers, the relationships we form and maintain within our classrooms, schools, and communities are at the heart of a community-based perspective on learning.

The Community-Based Master of Education program consists of eight courses ( 24 credit hours) as well as a six credit hour project. As a central part of the program, the action research project offers graduate students the opportunity to focus on an area of interest to improve their respective teaching practices (Friesen, 2007). As action research, these projects are based on a series of cycles of action and reflection, described by McNiff and Whitehead (2011), for example, as a process of identifying particular concerns or interests, followed by a trying out of different ways of addressing those concerns, and then reflecting on what has happened in order to explore further venues-illustrated in Appendix A as a cyclical sequence of steps (i.e., observe, reflect, act, evaluate, and modify). Educational action research is grounded in the firsthand experiences of practitioners as teacher-researchers ${ }^{1}$ who are involved in an immediate and direct way in thinking about and theorizing their own practice. This way of doing research, described as "a form of enquiry that enables practitioners in every job and walk of life to investigate and evaluate their work" (2011, p. 7), is revealed through the action research projects of the Community-Based Master of Education Program at the University of Regina. The purpose of this inquiry, however, is essentially to sharpen my understanding of action research and its potential, particularly within the social contexts of the communities in which the research of the cohort has been carried out. In this endeavour, I hope to contribute to the ongoing and evolving conversation on the prospect of educational action research as a way toward improving and understanding teaching (and research) practice.

This paper focuses in particular on the action research projects of two K-12 teachers of the Northwest Regional College (NWRC) cohort (2007-2009) enrolled in the Community-Based Master of Education program. These project reports, among others of the cohort, are available through the Office of Research and Graduate Studies on the Faculty of Education website at the University of Regina (University of Regina, 2010). While my intention was initially to conduct a broad study of the project reports of the entire NWRC cohort, I narrowed my focus eventually upon these two particular reports given their uniquely intergenerational perspective on teaching practice, as well as a noticeable progression of action research cycles that begins firmly in the classroom, while proceeding toward more inclusive sets of activities that involve families and communities well beyond the typical setting of classroom and school (see Appendices B \& C). 
While the project reports of the NWRC cohort normally involve research cycles that are community-based in nature, these two projects are illustrative of a developmentally progressive approach to community-based action research that serves potentially as one strategy upon which future graduate students enrolled in the program might draw upon.

Individual interviews were conducted and recorded online (with consent) though Skype with five select members of the NWRC cohort whose project reports were directed specifically to teaching practice. The interviews were subsequently transcribed and member-checked, and yet the transcript text produced through these interviews has been applied only sparingly in support of the project reports considered in this inquiry. In retrospect, the interviews may have been conducted too early in the research process, resulting in too many interview questions directed toward the project reports - while touching upon several points of interests, offered little in terms specifically of my emergent interest in the progression of action research cycles toward a community-based teaching practice, as observed in the two featured project reports. The narrative text of each of these research projects-narrative as "stories to live by" as Clandinin and Connelly (1998) once described it-offers a glimpse, however, of the experiences of each of the teacher-researchers as they progress through the reflective process of the action research cycles. Through a reading of these projects, I was reminded inevitably of my personal interests as an educator and the possible influence of that point of view upon the findings of this inquiry. As Elliot Mishler (1991) observed, "the researcher does not find narratives but instead participates in their creation" (as cited in Riessman, 2008, p. 21). I believe this to be true; the narrative text included in this inquiry is without question a select narrative that is grounded in my personal interests and concerns with community-based teaching and research practice as it impacts the relationships of schools with the communities they serve.

Given the interest of several of the cohort in the learning of Indigenous children and youth in their communities, I have drawn upon a small portion of the literature of Indigenous education, notably Jo-Ann Archibald's (2008) research on Indigenous storywork principles. ${ }^{2}$ The perspective taken through Indigenous story seems especially well suited to the cyclical and yet reflective nature of action research.

Stories go in circles. They don't go in straight lines. It helps if you listen in circles because there are stories inside and between stories, and finding your way through them is as easy and as hard as finding your way home. Part of finding is getting lost, and when you are lost you start to open up and listen. (Tafoya, 1995 as cited in Wilson, 2008, p. 6)

True to the reiterative nature of story, the storywork principles lend themselves to an understanding of community-based teaching practice informed by a more balanced, holistic view on learning with the power, as Archibald (2008) puts it, "to make our hearts, minds, bodies, and spirits work together" (p. 12). In her study, Archibald shares in narrative form the results of her research conducted in the company of three Coast Salish Elders and 13 Stó:lo Elders of the coastal region of British Columbia, who either were storytellers or were versed in the oral traditions of their people. Seven storywork principles emerge through her work with the Elders, including respect, responsibility, reciprocity, and reverence, as well as holism, interrelatedness, and synergy. 
I draw upon these principles in their entirety as a uniquely insightful perspective on learning with relevance to a community-based practice of teaching and research, with a focus in particular on the storywork principles of respect, responsibility, reciprocity, and reverence, while the remaining principles of interrelatedness, synergy, and holism serve in a no less important yet supportive role. Taken as a whole, Archibald (2008) summarizes these four leading storywork principles essentially as learning principles, including, a) respect for each other and cultural knowledge; b) responsibility for carrying out the roles of teacher and learner (a serious approach to the work and being mindful of what readers/other learners can comprehend); c) practicing reciprocity so that we each give to the other, thereby continuing the cycle of knowledge from generation to generation; and d) reverence for spiritual knowledge and one's spiritual being.

\section{From Classroom to Community}

In each of the two studies of this inquiry, a connection takes shape with communities of artists, for example, or with families and community members who have a genuine interest in the learning and wellbeing of the children and youth in their schools. In the first of the two action research projects, Jinny Nieviadomy (2009) explores the emergence of her identity as an artist, and in particular, its influence upon her art teaching. In the second project, John MacCormack (2009) focuses on his Group of Seven. These are students enrolled in a bridging program, which involved his work on resiliency skills with youth at-risk of dropping out (or failing out) of school.

While progressing through each of the action research cycles, these individuals in their unique ways appeared to develop a sense of identity as community-based educators, particularly through their interactions with others, reminiscent of Hannah Arendt (1994), who maintains that "we become one whole individual, through and only through the company of others. For our individuality, insofar as it is one-unchangeable and unmistakable-we depend entirely on other people” (p. 358). In the study of narrative, however, Yuval-Davis (2007 as cited in Riessman, 2008) surmises that identities are in effect narratives, the stories that we tell about who we are, and who we are not, that continually reproduce themselves "through the combined processes of being and becoming, belonging and longing to belong” (p. 8). In reading and reflecting upon each of the action research project reports, and in conversing with each of the contributing teachers, I believe there is within their respective narratives a desire, at least within the contexts of their research projects, to redefine themselves; that is, to redefine their identities as educators in relationship with communities of professionals, families, and others beyond the institutional setting of classroom and school. This seemed to become apparent to me as I witnessed the progression of research cycles, beginning with what may be described as everyday classroombased activities toward more collaborative (and perhaps, courageous) work with communities of local artists, for example, as well as the families of students in their classrooms.

\section{Emerging Identities}

In the first of the two action research projects, Jinny Nieviadomy (2009) explores through four successive action research cycles her emerging artist identity and its potential contribution to her practice as an art teacher. This process began with the first research cycle, a PowerPoint 
presentation of her artwork to separate classes of Grade 8 and 9 students, complemented by the second research cycle, an invitation to local artists (i.e., a potter and a photographer) to share their respective crafts. This budding relationship with the local art community continued, however, with the third research cycle, comprised of an interdisciplinary field trip to two local art galleries, followed by the fourth and final research cycle, which involved an art exhibit where students had the opportunity to display their artwork for their peers within the school setting (and potentially for parents, families and others within the local rural community served by the school).

Archibald (2008) describes her storywork principles as essentially weaving themselves metaphorically in and out of one another, so that no one principle truly stands alone. If one principle may be said to stand out in a study of the action research cycles featured in this research project, however, the storywork principle of reciprocity in particular seems to best define the maturing relationship between this teacher and her students. Jinny reports being especially apprehensive in deciding to show her artwork to a class of Grade 9 students; as she notes, "The fact that they have known me for a year, gave me some reassurance and comfort, but I was still nervous, shaky and talking extremely fast-not giving a lot of time for responses" (Nieviadomy, 2009, p. 22). Yet later, it is reported that, "Without prompt, two of my grade nine classes offered a round of applause to show their appreciation at the end of the PowerPoint show of my artwork” (p. 22). This is, at least in part, reflective of Archibald's (2008) description of the storywork principle of reciprocity, as illustrated, for example, through her work with Elder Ellen White, as being "ready to share and 'give back' to Ellen what I had learned from her-thereby practising the principle of reciprocity” (p. 57). One might surmise, then, that Jinny's students were able essentially to give back in this manner to their teacher a firm recognition of her skill and understanding of art (i.e., her artist identity), and through that acknowledgement have effectively started upon their own special paths toward an artist's identity.

As the initial research cycle, the PowerPoint presentation led to a further cycle that took the form of an invitation to local artists from the community. A local potter was contacted, in particular, to help introduce clay hand-building techniques, followed by a photographer to share her expertise not only on photography elements and composition, but also on aspects of photography as a profession or career. As a second research cycle, bringing in local artists to the classroom served in effect as a way of exposing students further to the concept of the working artist as part of their learning about art, yet also as a way of building personal connections between the classroom and the local art community.

Bringing artists into the classroom shows students the connection of classroom learning to the community beyond the school doors. I believe it is a very empowering experience for artists to know that a value is put on their practice and important enough to be studied in classrooms. Students will be able to take pride in knowing the talents of local artists in their community. (Nieviadomy, 2009, p. 28)

This evolving, and emerging, relationship between the students and the local art community took an additional step, however, through the third research cycle of an interdisciplinary field trip, which had begun earlier through collaborative work that Jinny had undertaken with the school's Language Arts teacher on a cross curricular unit on storytelling that involved the exploration of 
myths and legends, including the storytelling traditions of the First Nations. In particular, the trip included visits to both the Allen Sapp and Chapel Galleries ${ }^{3}$ in the city of North Battleford, Saskatchewan, featuring appearances by the artists at each gallery who spoke with the students about their artwork.

At the Chapel Art Gallery, artist Holly Hildebrand led an interactive discussion with this group of young artists about how the stories of her life and family provided the inspiration to create her exhibit of textile and printed works. In similar fashion, the group visited the Allen Sapp Gallery to view the original artwork of Allen Sapp accompanied by his personal stories about the events in his life and how they also contributed to his work. Jinny notes upon reflection, however, that the Gallery field trip "offered a new and exciting way for students to learn about art. Student participation in the Gallery field trip allowed them to see how storytelling is applied to art in the real world and how professional artists use it as a tool in their works and the different forms of storytelling. Stories do not always come from the pages of a book" (Nieviadomy, 2009, p. 29). Through their interactions with the local art communitywhether through guests invited to their classroom, or artists who spoke about their work at the art galleries - these students were able to observe, in particular, the importance of story to artwork and its connection with life and learning. This is experienced perhaps in a synergistic way, as Archibald (2008) describes it, through the interrelationship of the storyteller, the listener, and the story, as found in this instance through the artists, the students, and their artwork as storied life. This connection became especially significant, however, in the fourth and final research cycle, in which the young artists were given the opportunity to speak as artists about their own artworks.

The Local Artists' Gala as the start-up of the final action research cycle may be said to mark a turning point in Jinny's research project. Having experienced the display of her artwork within a public venue, she was prompted to encourage her art students to show their artwork to others, beginning with a sharing circle conducted within the safety of the classroom that provided each student with the "opportunity to share the experience that was the basis for their illustration" (Nievidadomy, 2009, p. 32), reminiscent of the interactive discussions they had with the artists at the galleries. The next step involved an exhibit of the students' work within the school setting, where it is observed, however, that several of them expressed apprehension in filling out their names on the title cards to accompany their finished projects; yet, "upon seeing the admirers and hearing the comments made about the artwork, the apprehension about being accountable for their artwork had disappeared" (p. 32). Through the Gala, as a final research cycle, Jinny was able to engage pedagogically with her students, mindful perhaps of Walter Lightning's (1992) observations of his work with Elder Louis Sunchild, who speaks of minds engaged in mutual discourse; that is,

[L]earning is not a product of transferring information between a teacher and a student. It is a product of creation and re-creation, in a mutual relationship of personal interaction, of information. It is not just a cognitive (mental) act, but an emotional—thus physical—act. Learning is felt. (p. 232)

The relationship of Jinny, as a teacher engaged in the learning process with her students, as conveyed through her emerging and maturing identity as a working artist, and further, as a member of the local art community, seems to me the constant that runs throughout each of the 
four research cycles, including the Gala at the end of the project. In this way, the learning experience for teacher and students alike may be said to be truly reciprocal as it involves not simply a transfer, or dissemination, of knowledge, but instead a re-creation of knowledge, as Lightning (1992) observes, that is dependent on the sustained and mutual relationships between Jinny and her students.

\section{Fostering Resiliency Skills}

The sense of mutuality felt between teacher and student, as a trust that is built on the dayto-day experiences of a teacher with his students, is at the heart of John's action research project on the development of resiliency among Indigenous youth. John focuses on seven students (i.e., the Group of Seven) of his bridging class, described as a program "to address the issues the students face and make it possible for them to complete their academic tasks in a caring and welcoming environment” (MacCormack, 2009, p. 22). This group includes four boys and three girls, ranging in ages from 16 to 20 years with two of the three girls who are single mothers. Among the four boys, one is described as a single father and 19 years of age, while the other boys are younger and with problems of substance abuse.

This study of resiliency opens with an incident in a school hallway, involving one of the boys of the Group of Seven, facing suspension after being engaged in a heated verbal exchange with a school staff member. A second research cycle follows in response to the problem of absenteeism among two other of his bridging students, both single mothers, which took the form of a program involving the delivery by a school community worker of lessons and activities to their homes so that the students would not fall behind in their studies. The third and final research cycle involves what John refers to as the Bridging Supper with the invitation of parents, family, relatives, friends, and other interested community members to recognize and celebrate the successful completion by the Group of Seven of their high school graduation.

The boy at the start of it all, at the centre of the hallway incident, had returned to school after serving his 3-day suspension. Following his return, John took the opportunity to speak with him about his current situation, and later reflected upon the conversation in his journal.

Dwight [pseudonym] and I had a great discussion. He has just returned from his suspension ... [W]e chatted about his life and who lives at his home. He misses his little boy, whose birthday is approaching. He has no real guidance or connections i.e., positive bonds or role models that I can tell of. There is no one who really cares for him and he has had an absentee father (jail) for most of his life . . . I don't think any real boundaries were ever taught to him. (MacCormack, 2009, p. 26)

After his return to school, however, Dwight had begun to experience significant academic progress toward meeting the requirements for his high school graduation. Upon reflection, John observes that this first research cycle, "though innocuous, was extremely powerful" (MacCormack, 2009, p. 27); while noting further, "This incident made me aware of the result that can blossom from seemingly small or minor events. I was able to use my newly developed framework that incorporates my understanding of resiliency to form my actions and to better understand how I can help students” ( p. 27). This realization, indicative of the action research 
process, led at least in part to a second research cycle that was designed to address the problem of absenteeism experienced by two other students of the bridging program, both of whom were single mothers.

John describes the circumstances that had prompted him to pursue this particular direction in his research. Neither of the two students had home telephones, nor did either of them have a cell phone. Both lived several kilometres from the school. John proceeded, then, to approach the school community worker to deliver to the students' residences on a regular basis his package of lessons and activities so that they would not fall too far behind in their studies. Importantly, the package also contained a letter to the students kindly inquiring whether or not they would be able to return soon, and further, as he points out, "whether or not they were in a safe environment [followed with] a general salutation of good will for them" ( MacCormack, 2009, p. 29). This action research cycle was called the Pony Express.

As the third and final research cycle, the Bridging Supper took shape out of a desire to reward the Group of Seven for their progress. John recounts the significance of this event.

Having food was not the focus of the supper; the important part was creating healthy relationships between all of the people in their lives who can provide support and encouragement: teachers, family, students, and community members. . . . The supper was a huge success because we bonded in a way that was out of the norm, so to speak, and the students were able to witness some caring and support. There were opportunities for meaningful participation as everyone had a chance to speak at the supper table and identify who they were and how they were connected to the supper or to the students. It is clearly evident there was positive bonding occurring because of the respect shown to all those in attendance. The students knew they were the focus of this supper and they relished the experience. High expectations for success were anticipated and fulfilled. (MacCormack, 2009, p. 34)

Perhaps the most salient point of the supper, as with the action research cycles in their entirety, was their role in interrupting "a pattern of apathy towards school” (MacCormack, 2009, p. 32), reminiscent of the ethic of care, whereby caring is "an attribute of relations in which the 'carer' contributes in a distinctive way and the 'cared for' contributes by recognizing the efforts of the carer" (Noddings, 2005, p. 70). The ethic is illustrated further, however, through a telling remark in interview on the Bridging Supper and its impact upon the students: "What was mind blowing mostly was that when I told them that I wanted to have a dinner basically in their honor, you could have heard a pin drop. It was so quiet. They were shocked that somebody would take the time to consider” (Interview, February 1, 2011).

Underlying John's relationship with his students is an attitude toward teaching that is perhaps best marked by the storywork principle of respect. Taken from a Eurocentric point of view, Arendt (1958) remarks upon the manner in which respect, as principle, has come to be understood; that is, she observes, that respect "is a regard for the person from the distance which the space of the world puts between us, and this regard is independent of qualities which we may admire or of achievements which we may highly esteem” (p. 243). This implicit understanding of what it means to be respectful, and to be respected, independent of qualities or competencies 
that we may hold in high regard (attributed perhaps to Arendt's reading of St. Augustine) is contrasted, however, with the commonly held, and depersonalizing, view that respect is due "only where we admire or esteem" (p. 243). Reminiscent of Arendt's explanation of what the principle of respect, at least, ought to imply, Archibald (2008) reflects upon her interview with Elder Simon Baker, who "stressed the importance of living honorably and showing respect to everyone, even if you dislike a person. In time, this respect could be returned to you" (p. 43). This view of respect as a principle indifferent to achievement, position, or disposition is perhaps best exemplified, however, through John's telling narrative of how the character of Atticus Finch in Harper Lee's novel, To Kill a Mockingbird, is likened to the life of his beloved uncle.

I particularly liked how Atticus would do lawyering work for people, and never charged them money as they couldn't pay. He knew that, but still gave them the honorable ability to pay with their cattle, or their grain, or whatever it happened to be. And I thought that's my uncle to a tee because he would go around from church to church and do these little miracles, things that the priests or anybody else didn't know about. And so, I always have believed that people are good, and no matter whether you are of a high or low echelon, you need to be treated with respect. That, for me as a teacher, is probably the pinnacle of what it means to be a good teacher, respecting people no matter where they come from, and giving them an opportunity, like Atticus, to pay their way. Nobody really wants a free ride. They want to feel wanted. They want to feel that they belong, and that they've got something to contribute. (Interview, February 1, 2011)

Through the example of Atticus, or the life of John's uncle, the storywork principle of respect lends itself to a sense of belonging, suggestive of the Circle of Courage (Bendtro, Brokenleg, \& Van Bockern, 2002), or as Archibald (2008) suggests, a feeling of kinship or interrelatedness. Novelist Thomas King, for instance, speaks of the Indigenous notion of living with all my relations as a reminder of who we are in our relationships with family, yet also our extended relationships with other human beings, our kinship with animals, birds, fish, plants, and all animate and inanimate forms of life, that serves as a reminder to "accept the responsibilities we have within this universal family by living our lives in a harmonious and moral manner" (1990, p. ix as cited in Archibald, 2008, p. 42). In this sense, the principle of respect is, and ought to be, implicitly unconditional.

\section{It Really Does Take a Village}

In both of the action research projects considered in this inquiry, these teacherresearchers have moved essentially from the relatively private space of the classroom, housed within the institutional environment of the school, toward a more publicly engaged space within their respective communities of interest. Characterizing each of these projects, however, is a uniquely intergenerational quality reflected through the storywork principle of responsibility, found especially in the early reference by both authors to notable individuals in their lives who were significant in their growth and development as teachers. Archibald (2008) tells us that according to the teachings of her Nation, the Stó:lo Nation, knowledge and wisdom bring power, and, "If one comes to understand and appreciate the power of a particular knowledge, then one must be ready to share and teach it respectfully and responsibly to others in order for this knowledge, and its power, to continue” (p. 3). Learning in this sense conveys a special 
responsibility in caring for the next generation, as reflected in the narratives of each action research project.

The parting with knowledge and the sense of power and wellbeing experienced by others is central to the principle of responsibility. Jinny, for example, recalls the influence of a high school art teacher and how she had passed on knowledge and insight about the practice of making art that, importantly, served in both an instructional and inspirational sense in teaching art.

I remember being the student that looked over her shoulder, curious to see what she was doing and how she was doing it. ... Through her vast knowledge of art theory, techniques and creation of her own work, my grade twelve art teacher empowered me as a student through meaningful art experiences. She allowed me to be a collaborator and facilitator of my own learning in art class making it a meaningful experience. (Nieviadomy, 2009, pp. $1-2)$

Similarly, John recounts the passing of his Uncle Angus, notably his funeral, and the special way in which his beloved uncle was remembered.

One priest needed some clothes for the poor and, one morning sitting on the altar, there was a box of good, used clothes. Another priest shared a story about a borrowed chalice that was supposed to have been returned to his church and, with time running out, he was going to have to make do with something less ceremonial. When he opened his church for the first mass of the day, he discovered the borrowed chalice in its rightful place on the altar. ... He made things happen but never required any type of thanks or manner of appreciation. He did these things because they had needed to be done. I learned much from my Uncle Angus and, in death, he still had lessons to teach me. (MacCormack, 2009, p. 4)

In each instance a special and notable individual is credited with having passed on valuable knowledge about life and learning, reminiscent of Elder Vincent Stogan's hands back, hands forward teaching:

In joining hands, hold your left palm upward to reach back to grasp the teachings of the ancestors. Put these teachings into your everyday life and pass them on. Hold your right palm downward to pass these teachings on to the younger generation. In this way, the teachings and knowledge of the ancestors continue, and the circle of human understanding and caring grows. (Archibald, 2008, p. 50)

The passing on (and reception) of a storied life from one to another, as Archibald (2008) phrases it, whether through art and the art community, or through the many inter-relationships found through family and friends, is at the heart of the storywork principle of responsibility.

Closely interwoven with the storywork principles of reciprocity, respect, and responsibility, Archibald (2008) notes the importance of reverence, as a principle defined through prayer and spirituality, yet also though language and speech within an Indigenous 
framework as depicted, for example, by Lee Maracle of the Stó:lo/Coast Calish Nation, who speaks of the spiritual reverence for oratory, as words that "represent the accumulated knowledge, cultural values, the vision of an entire people or peoples" (p. 26). Wane (2005) offers a further perspective, however, on an Indigenous (African) way of knowing, referring in particular to the need to preserve its transcendent and holistic nature, and in addition "its reverence for the community, the earth, and the dignity it holds for life and living” (p. 19). The action research projects considered in this study are reflective of reverence as a learning principle in this especially communal sense, for example, through Snodgrass's (2009) collaborative work with a local radio station operator in the production of a radio broadcast by his high science school students, or through Keen's (2009) study of place-based education that featured an activity with his Grade 5 class, focusing on the beautification of a small gully located nearby their school that required ongoing collaboration with local farmers and town council members. In their entirety, however, the five action research projects initially included in this inquiry offer what might be considered a broader, perhaps an alternative, vision of education for the children and youth in our schools. Such a vision may be said to take shape through the collaborative ventures that involve, for example, local art communities, radio station operators, town councils, law enforcement officers, or parents and families, all characteristic of what Handspiker (2009) refers to in his action research project as community/educational partnerships; that is, as Bendtro, Brokenleg, and Van Bockern (2002) observe, all adults in traditional Indigenous society were responsible for the education and upbringing of children and youth, whereby, "Child rearing was not just the province of biological parents, but children were nurtured within a larger circle of significant others. From the earliest days of life, the child experienced a network of caring adults” (p. 46). This is a view toward life and learning that is fundamentally community-based.

The idea of an entire community, including schools, charged with the care and responsibility for the upbringing of children and youth (evocative of the African proverb, "It takes a village to raise a child" as cited in Tymchak, 2001) is reflective of the work undertaken through the action research projects considered in this inquiry, and moreover, those of the NWRC cohort upon which they were drawn. Common among these research projects is a firm acknowledgement of the contribution to be made by communities of professional practitioners beyond the institutional space of the school, as well as the families of students, who are valued for their spirit of care and generosity as educational partners-as Handspiker (2009) puts it, the “community becomes the teacher” (p. 14). It really does take a village.

\section{The Potential of Community-Based Action Research}

Through community-based action research, educators have the opportunity to redefine their teaching practice as reflective practice carried out as they progress from one research cycle to the next. In the two projects featured in this inquiry, both contributing teachers appear to redefine their respective teaching practices in terms more in tune with their communities of interest beyond the realm of classroom and school. Each research project progresses systematically, yet intuitively, through the action research cycles, beginning with a classroom-based perspective, only to expand their respective research projects to include communities (i.e., local art communities, family and other community members) as part of an emergent community-based teaching and research practice. This is a strategy (whether intended or not) that may serve well 
for future graduate cohorts of the Community-Based Master of Education program that remains true to the cyclic nature of the Action-Reflection Model (see McNiff \& Whitehead, 2011).

The call for teachers and schools to work more collaboratively with families, as well as with professional communities has been addressed, for example, by Tymchak (2001) in SchoolPLUS: A Vision for Children and Youth, who recommends essentially that schools become part of a human-service agency network that would involve collaborative work with healthcare and other social welfare agencies. In a similar light, Sackney (2007) makes reference to the school improvement movement of the 1990s (e.g., Alberta Initiative for School Improvement; Ontario's Educational Quality and Accountability Office) that among other points of interest had pushed for more involvement by parents in the education of their children in meaningful ways beyond contributing their time, for example, to fundraising or the supervision of extracurricular activities. Considerable attention has been given to the issue of parental involvement, or engagement, in schools (e.g., Pushor \& Murphy, 2004, 2010; Stelmach, 2004; Stelmach \& Preston, 2008; Winton, 2010; Epstein 2011). As part of this conversation, however, Ippolito (2010) considers the issue of parental involvement, framing the question as a dichotomy that exists between school-centred and family-centred points of view with "the former arguing for families aligned to schools and the latter arguing for schooling aligned to families” (para. 7); that is,

The gulf between mainstream schools and families, in particular minority families, can be vast, but bridging this gulf by pulling parents on to the shores of the school or, conversely, pulling the school on to the banks of the home is short-sighted. Both options diminish possibility for schools and families to mutually-specify each other in ways that promote balanced, progressive, respectful, and ethical relationships. (Ippolito, 2010, para. 39)

A common, research-informed conversation is suggested as a workable alternative, in which teachers as researchers may find themselves situated within a public space, or middle space, for collective learning (Ippolito, 2010) that affords them opportunities to engage collaboratively and commonly with communities (e.g., families and professional communities) beyond classroom and school in the development of educational programs for children and youth.

Within this publicly-engaged and collaborative framework, community-based action research has the potential as a means for teachers to improve and expand upon their professional practice. Action research may be conducted collaboratively with colleagues, for example, as a normal part of one's teaching practice through school-based professional learning communities. Yet further opportunities may be found in working with parents, families, and other professional communities that exist beyond classroom and school in their particularly institutional sense. Action research as a collaborative endeavour may serve well toward the development of sustained relationships with others beyond the school setting, so essential to a community-based teaching practice. 


\section{References}

Archibald, J. (Q'um Q’um Xiiem). (2008). Indigenous storywork principles: Educating the heart, mind, body, and spirit. Vancouver: UBC Press.

Arendt, H. (1958). The human condition (2nd ed.). Chicago: The University of Chicago Press.

Arendt, H. (1994). Essays in understanding, 1830-1954/Hannah Arendt. J. Kohn, (Ed.). New York: Hartcourt Brace.

Bendtro, L., Brokenleg, M., \& Van Bockern, S. (2002). Reclaiming youth at risk: Our hope for the future (2nd ed.). Bloomington, IN: National Education Service.

Bopp, M., \& Bopp, J. (2006). Recreating the world: A practical guide to maintaining sustainable communities (2nd ed.). Calgary, AB: Four Worlds Press.

Clandinin, J., \& Connelly, M. (1998). Stories to Live by: Narrative understandings of school reform. Curriculum Inquiry, 28(2), 149-164.

Elliot, J. (2009). Building educational theory through action research. In S. Noffke \& B. Somekh (Eds.), The Sage handbook of educational action research (pp. 28-38). Los Angeles: Sage.

Epstein, J. (2011). School, family, and community partnerships: Preparing educators and improving schools. Boulder, CA: Westview Press.

Friesen, D. (2007). Project manual: Community-based Master of Education Program. Regina, SK: University of Regina.

Handspiker, T. (2009). The community in my classroom, my classroom in the community. Retrieved from http://education.uregina.ca/index.php?q=GradStudentWork.html

Ippolito, J. (2010). Minority parents as researchers: Beyond a dichotomy in parent involvement in schooling. Canadian Journal of Educational Administration and Policy, 114. Retrieved from http://www.umanitoba.ca/publications/cjeap/articles/comm-toc.html

Keen, B. (2009). Turtleford community school place-based education. Retrieved from http://education.uregina.ca/index.php?q=GradStudentWork.html

Lightning, W. (1992). Compassionate mind: Implications of a text written by Elder Louis Sunchild. Canadian Journal of Native Education, 19(2), 215-53.

MacCormack, J. (2009). How can I promote resiliency in youth? Retrieved from http://education.uregina.ca/index.php?q=GradStudentWork.html

McNiff, J., \& Whitehead, J. (2011). All you need to know about action research. Los Angeles: Sage. 
Nieviadomy, J. (2009). Artist as teacher as artist. Retrieved from http://education.uregina.ca/index.php?q=GradStudentWork.html

Noddings, N. (2005). Teaching: A lifelong moral quest. In S. D. Hatton (Ed.), Teaching by heart: The Foxfire interviews (pp. 66-71). New York: Teachers’ College Press.

Pushor, D., \& Murphy, B. (2004). Parent marginalization, marginalized parents: Creating a place for parents on the school landscape. Alberta Journal of Educational Research, 50(3), 221235.

Pushor, D., \& Murray, B. (2010). Schools as protectorates: Stories two Mi’kmaq mothers tell. Canadian Journal of Educational Administration and Policy, 114. Retrieved from http://www.umanitoba.ca/publications/cjeap/articles/comm-toc.html

Riessman, C. (2008). Narrative methods for the human sciences. Los Angeles: Sage.

Sackney, L. (2007). History of the school effectiveness and improvement movement in Canada over the past 25 years. In T. Townsend (Ed.), International handbook of school effectiveness and improvement (pp. 167-182). Dordrecht/London: Springer.

Snodgrass, J. (2009). Improving my practice using experiential learning: An action research project. Retrieved from http://education.uregina.ca/index.php?q=GradStudentWork.html

Stelmach, B. (2004). Unlocking the schoolhouse doors: Institutional constraints on parent and community involvement in a school improvement initiative. Canadian Journal of Educational Administration and Policy, 31. Retrieved from http://www.umanitoba.ca/publications/cjeap/articles/stelmach.html

Stelmach, B, \& Preston, J. (2008). Cake or curriculum? Principal and parent views on transforming parental role in Saskatchewan schools. International Studies in Educational Administration, 36(3), 59-74.

Tymchak, M. (2001). Task Force and public dialogue on the role of the school: SchoolPLUS: A vision for children and youth, final report. Regina, SK: University of Regina, Faculty of Education, Saskatchewan Instructional Development \& Research Unit (SIDRU).

University of Regina. (2010). Dissertations, theses and projects. Retrieved from http://education.uregina.ca/index.php?q=GradStudentWork.html

Wane, N. (2005). African Indigenous knowledge: Claiming, writing, storing, and sharing the discousrse. Journal of Thought, 40(2), 27-46.

Wilson, M. (2008). Research is ceremony: Indigenous research methods. Halifax, NS/Winnipeg, MB: Fenwood Publishing. 
Winton, S. (2010). Democracy in education through community-based policy in dialogues. Canadian Journal of Educational Administration and Policy, 114. Retrieved from http://www.umanitoba.ca/publications/cjeap/articles/comm-toc.html 


\section{Appendix A}

Action-Reflection Cycle

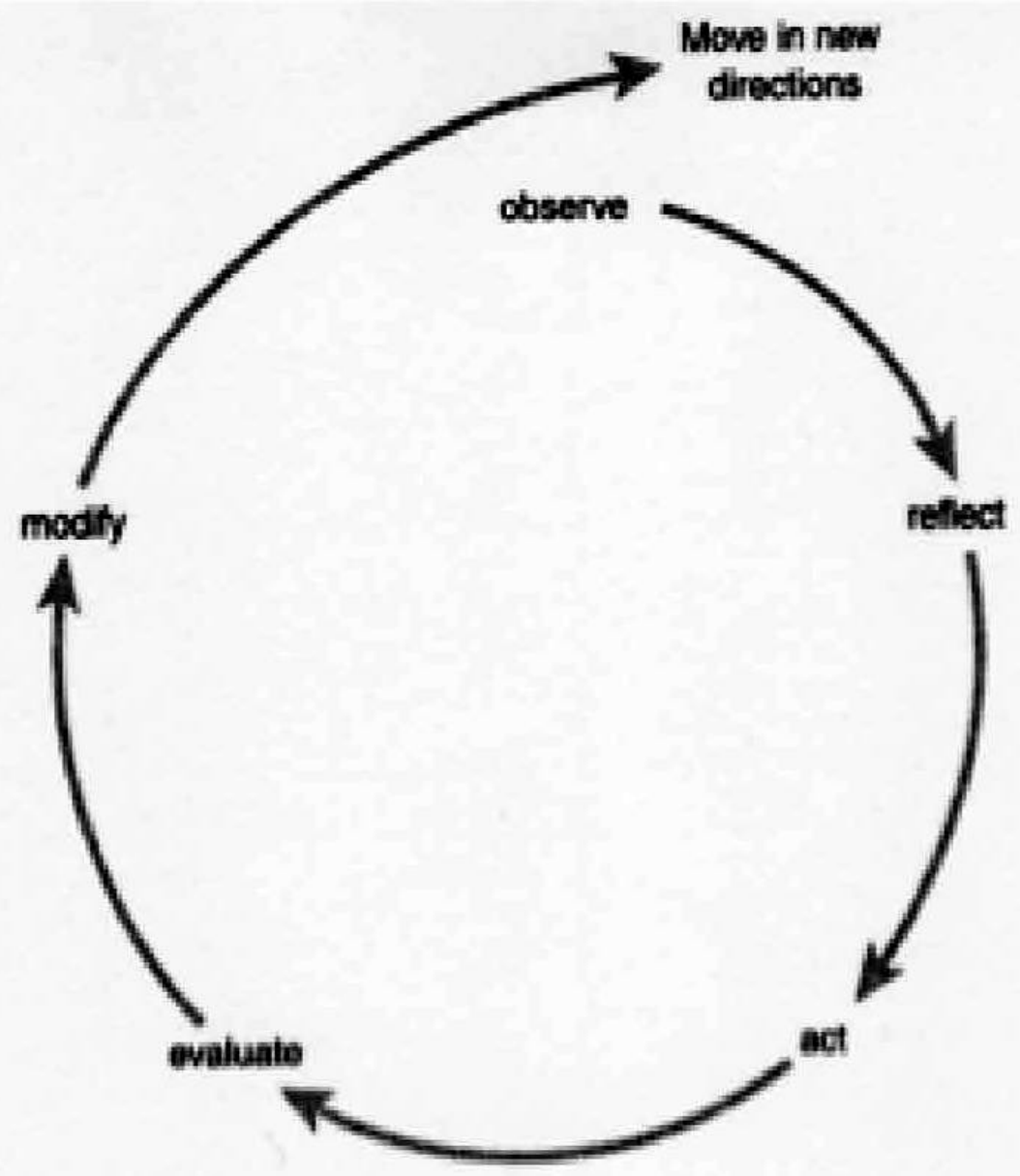

McNiff \& Whitehead (2011, p. 9) 


\section{Appendix B}

Action Research: From Classroom To Community

\section{Action research as community-based}

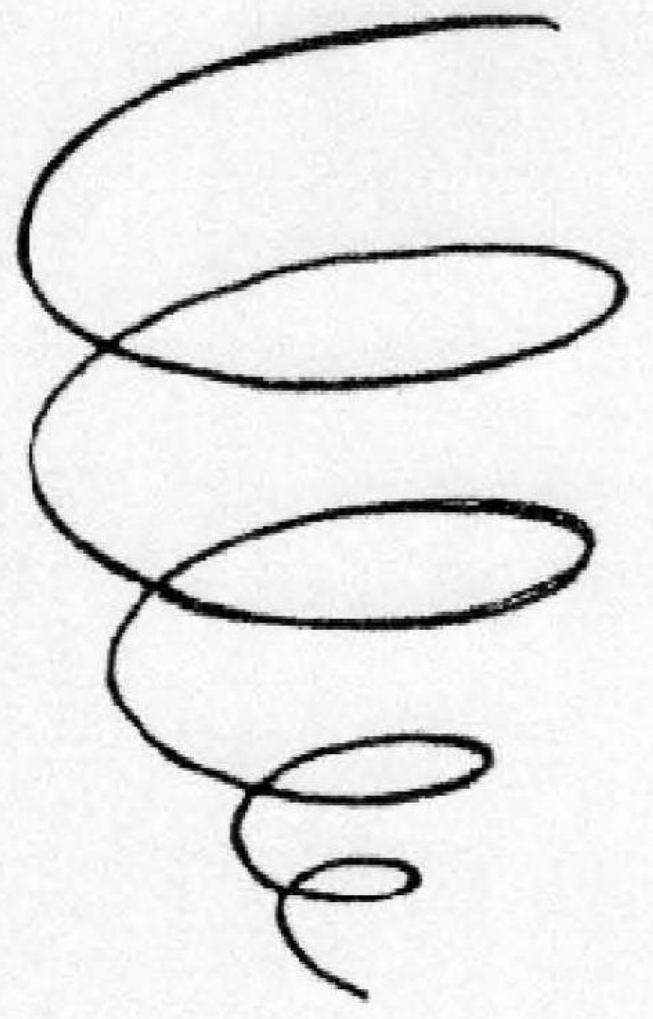

4th action research cycle

3rd action research cycle

2nd action research cycle

1 st action research cycle

\section{Action research as classroom-based}

Spiral image, retrieved from http://www.stanleywilliamhayter.com/anglais/structure_a.htm

\section{Appendix C}

Action Research Cycles

MacCormack (2009)

(1) An incident in the hallway

(2) The pony express

(3) The bridging supper 
Nieviadomy (2009)

(1) A PowerPoint presentation

(2) Local artists as guest teachers

(3) An interdisciplinary field trip

(4) An art exhibit

\section{End Notes}

${ }^{1}$ Action research arises, at least in part, out of the experiences of teachers as 'teacher-researchers' as noted by Elliot (2009), who refers to his work as a teacher-researcher involved in the schoolbased curriculum development movement in the United Kingdom during the mid-1960s.

Lawrence Stenhouse is credited with having coined the phrase 'teachers as researchers' with an emphasis on the development of shared practical understandings among teachers engaged in reflective educational research (Elliot, 2009).

${ }^{2}$ The term "Indigenous" is applied within the framework of Archibald's (2008) usage of the term as explained in her Preface to Indigenous Storywork: References to terms such as 'Indigenous,' 'First Nation,' or 'Indian' are meant to include all people of Aboriginal ancestry. The term 'storywork' is reflective of the need for Indigenous stories to be taken seriously; that is, "to demonstrate that Indigenous knowledge systems could be investigated from an Indigenous perspective with rigour acceptable to the academy” (Archibald, 2008, p. 5)

${ }^{3}$ For information about artist Holly Hildebrand, see http://www.artistsincanada.com/homepage/?id=13570\&page=resume; for a biography of Allen Sapp and his artwork, see http://www.allensapp.com/about/life_and_art.php 